CLINICAL STUDY

\title{
Distinct effects of pioglitazone and metformin on circulating sclerostin and biochemical markers of bone turnover in men with type 2 diabetes mellitus
}

\author{
A H van Lierop ${ }^{1}$, N A T Hamdy ${ }^{1}$, R W van der Meer ${ }^{2}$, J T Jonker ${ }^{1}, \mathrm{H}$ J Lamb ${ }^{2}$, L J Rijzewijk ${ }^{3}$, M Diamant $^{3}$, \\ J A Romijn ${ }^{1}$, J W A Smit ${ }^{1}$ and S E Papapoulos ${ }^{1}$ \\ Departments of ${ }^{1}$ Endocrinology and Metabolic Diseases and ${ }^{2}$ Radiology, Leiden University Medical Center, Albinusdreef 2, 2333 ZA Leiden, \\ The Netherlands and ${ }^{3}$ VU University Medical Center, Diabetes Center, Amsterdam, The Netherlands \\ (Correspondence should be addressed to S E Papapoulos; Email: m.v.iken@lumc.nl)
}

\begin{abstract}
Objective: Patients with type 2 diabetes mellitus (T2DM) have an increased risk of fractures and thiazolidinediones (TZDs) increase this risk. TZDs stimulate the expression of sclerostin, a negative regulator of bone formation, in vitro. Abnormal sclerostin production may, therefore, be involved in the pathogenesis of increased bone fragility in patients with T2DM treated with TZDs.

Methods: We measured serum sclerostin, procollagen type 1 amino-terminal propeptide (P1NP), and carboxy-terminal cross-linking telopeptide of type I collagen (CTX) in 71 men with T2DM treated with either pioglitazone (PIO) (30 mg once daily) or metformin (MET) (1000 mg twice daily). Baseline values of sclerostin and P1NP were compared with those of 30 healthy male controls.

Results: Compared with healthy controls, patients with T2DM had significantly higher serum sclerostin levels ( 59.9 vs $45.2 \mathrm{pg} / \mathrm{ml}, P<0.001$ ) but similar serum $P 1 N P$ levels (33.6 vs $36.0 \mathrm{ng} / \mathrm{ml}, P=0.39$ ). After 24 weeks of treatment, serum sclerostin levels increased by $11 \%$ in PIO-treated patients and decreased by $1.8 \%$ in MET-treated patients $(P=0.018)$. Changes in serum sclerostin were significantly correlated with changes in serum CTX in all patients $(r=0.36, P=0.002)$ and in PIO-treated patients $(r=0.39, P=0.020)$, but not in MET-treated patients $(r=0.17, P=0.31)$.

Conclusions: Men with T2DM have higher serum sclerostin levels than healthy controls, and these levels further increase after treatment with PIO, which is also associated with increased serum CTX. These findings suggest that increased sclerostin production may be involved in the pathogenesis of increased skeletal fragility in patients with T2DM in general and may specifically contribute to the detrimental effect of TZDs on bone.
\end{abstract}

European Journal of Endocrinology 166 711-716

\section{Introduction}

Patients with type 2 diabetes mellitus (T2DM) have an increased risk of fractures (1), but the mechanism(s) responsible for the increased bone fragility remain unclear. Moreover, blood glucose-lowering therapy using thiazolidinediones (TZDs) has also been reported to cause bone loss (2) and to further increase the risk of fractures $(3,4)$. Activation of PPAR $\gamma$ and preferential stimulation of the differentiation of bone marrow mesenchymal stem cells into adipocytes at the expense of osteoblasts have been proposed as potential mechanisms for these effects of TZDs on bone (5). TZDs have also been recently reported to stimulate sclerostin synthesis in vitro, suggesting an additional mechanism for the detrimental effects of TZDs on bone (6). Sclerostin is a glycoprotein synthesized in bone by osteocytes, which reduces bone formation $(7,8)$, and serum sclerostin levels have been found to be significantly correlated with fracture risk in postmenopausal women (9). Abnormal sclerostin production may contribute to the pathogenesis of bone fragility of patients with T2DM as well as in the actions of TZDs on bone. To test this hypothesis, we measured serum sclerostin and biochemical markers of bone turnover in men with T2DM before and after treatment with the TZD pioglitazone (PIO).

\section{Materials and methods}

We studied 71 men with T2DM who participated in the PIRAMID study (PIO Influence on Triglyceride Accumulation in the Myocardium in Diabetes). The design and results of this study (10) as well as other metabolic parameters of the patients including whole body insulin sensitivity (11) have been reported previously. In brief, this was a 24 -week prospective, 
randomized, double-blind, double-dummy with active comparator, two-center parallel group intervention study. Men with uncomplicated T2DM, aged 45-65 years, were included in the study. After a 10-week washout period of previous medications, patients were treated with glimepiride for 8 weeks and were subsequently randomized to PIO (15 mg once daily, titrated to $30 \mathrm{mg}$ once daily after 2 weeks) or metformin (MET) $(500 \mathrm{mg}$ twice daily, titrated to $1000 \mathrm{mg}$ twice daily) and matching placebo to be taken in addition to glimepiride throughout the study. Blood samples were collected after an overnight fast at baseline and after 24 weeks of treatment and were stored at $-80{ }^{\circ} \mathrm{C}$ until assayed.

Baseline data including serum sclerostin and P1NP values were compared with those of 30 previously described healthy male volunteers (12). All these subjects had normal serum calcium concentrations, renal function, and bone turnover markers and were not using medications that could affect calcium or bone metabolism.

The study was approved by the medical ethics committees of the two participating centers, and informed consent was obtained from all the participants in the study.

\section{Serum biochemistry}

Sclerostin was measured by a highly sensitive electrochemiluminescence assay (Mesoscale Discoveries, Goithersburg, MD, USA) as described previously (13). The intraprecision of the assay was $6 \%$ and the interprecision $10 \%$. All samples from individual patients were measured in the same assay. Serum calcium adjusted for albumin binding, phosphate, and creatinine were measured by semiautomated techniques. Procollagen type 1 amino-terminal propeptide (P1NP) and carboxy-terminal cross-linking telopeptide of type I collagen (CTX) were measured by the E-170 system (Roche BV).

\section{Statistical analysis}

Data are expressed as mean \pm s.D. (unless otherwise stated). Absolute changes and percentage changes in biochemical parameters between baseline and endof-study values were calculated for each subject. Differences between groups were assessed by Student's $t$-tests. Differences in sclerostin levels between patients and healthy controls were corrected for BMI and weight using a linear mixed model. Within-treatment group differences in percentage changes in measured parameters were tested by one-sample $t$-test. Correlations were assessed by Pearson's correlation tests. Statistical analysis was performed using the SPSS 17.0 software (SPSS, Inc., Chicago, IL, USA). A P value of $<0.05$ was considered to be statistically significant.

\section{Results}

\section{Baseline}

The mean age of patients with T2DM $(56.5 \pm 5.6$ years $)$ was comparable with that of controls $(55.0 \pm 16.4$ years, $P=0.50$ ), but patients were overweight (patients: $92.2 \pm 13.6 \mathrm{~kg}$, controls: $80.7 \pm 12.1 \mathrm{~kg}, \quad P<0.001$ ) and had a higher BMI (patients: $28.7 \pm 3.4 \mathrm{~kg} / \mathrm{m}^{2}$, controls: $25.4 \pm 4.0 \mathrm{~kg} / \mathrm{m}^{2}, P<0.001$ ) (Table 1).

Patients with T2DM had significantly higher serum sclerostin levels compared with healthy controls $(59.9 \mathrm{pg} / \mathrm{ml} ; 95 \%$ CI: 55.2 to 64.8 and $45.2 \mathrm{pg} / \mathrm{ml}$; 95\% CI: 40.6 to $49.8 \mathrm{pg} / \mathrm{ml}, P<0.001$ ) (Fig. 1 A). This difference in sclerostin levels remained significant after adjusting for BMI or weight $(P=0.008)$. In patients with T2DM, serum sclerostin levels were positively correlated with serum fasting insulin levels $(r=0.41$, $P<0.001)$, but not with HbA1c $(r=0.07, P=0.57)$, weight $(r=0.07, P=0.58)$, or BMI $(r=0.18, P=0.12)$. There was no difference in mean serum P1NP levels between patients and controls $(33.6 \mathrm{ng} / \mathrm{ml}$; 95\% CI: 31.0 to $36.6 \mathrm{ng} / \mathrm{ml}$ and $36.0 \mathrm{ng} / \mathrm{ml} ; 95 \%$ CI: 30.7 to $40.8 \mathrm{ng} / \mathrm{ml}$ respectively, $P=0.39$ ) (Fig. 1B).

\section{Response to treatment}

There was no significant difference in age, weight, and time since diagnosis of T2DM between the two treatment groups (Table 2). Baseline values and changes in plasma glucose, insulin, and HbAlc after 24 weeks of treatment have been previously reported (10). Baseline values were similar in the two treatment groups and improved significantly, resulting in a similar degree of glycemic control during the 24 weeks of treatment with either MET or PIO.

Baseline values of serum sclerostin and of biochemical markers of bone turnover and calcium metabolism were similar between the two treatment groups (Table 2). The two treatment regimens had, however, different effects on serum sclerostin and bone marker levels (Fig. 2). Serum sclerostin levels increased by $11 \%(95 \%$ CI: 2.26 to $19.8, P=0.019)$ after 24 weeks of treatment with PIO, but there was no

Table 1 Baseline anthropometric and biochemical data of male patients with T2DM and healthy controls. Values are given as mean \pm S.D.

\begin{tabular}{lccc}
\hline & $\begin{array}{c}\text { Controls } \\
(n=30)\end{array}$ & $\begin{array}{c}\text { Patients } \\
(n=71)\end{array}$ & $\boldsymbol{P}$ value \\
\hline Age (years) & $55.0 \pm 16.4$ & $56.5 \pm 5.6$ & 0.59 \\
Weight $(\mathrm{kg})$ & $80.7 \pm 12.1$ & $92.2 \pm 13.6$ & $<0.001$ \\
BMl $\left(\mathrm{kg} / \mathrm{m}^{2}\right)$ & $25.4 \pm 4.0$ & $28.6 \pm 3.3$ & $<0.001$ \\
Sclerostin $(\mathrm{pg} / \mathrm{ml})$ & $45.2 \pm 12.8$ & $59.2 \pm 19.4$ & $<0.001$ \\
P1NP $(\mathrm{ng} / \mathrm{ml})$ & $36.0 \pm 13.8$ & $33.8 \pm 12.2$ & 0.43 \\
CTX $(\mathrm{pg} / \mathrm{ml})$ & - & $311 \pm 14$ & \\
Calcium $(\mathrm{mmol} / \mathrm{l})$ & $2.27 \pm 0.10$ & $2.29 \pm 0.10$ & 0.36 \\
Phosphate $(\mathrm{mmol} / \mathrm{l})$ & $1.05 \pm 0.12$ & $0.99 \pm 0.17$ & 0.41 \\
\hline
\end{tabular}



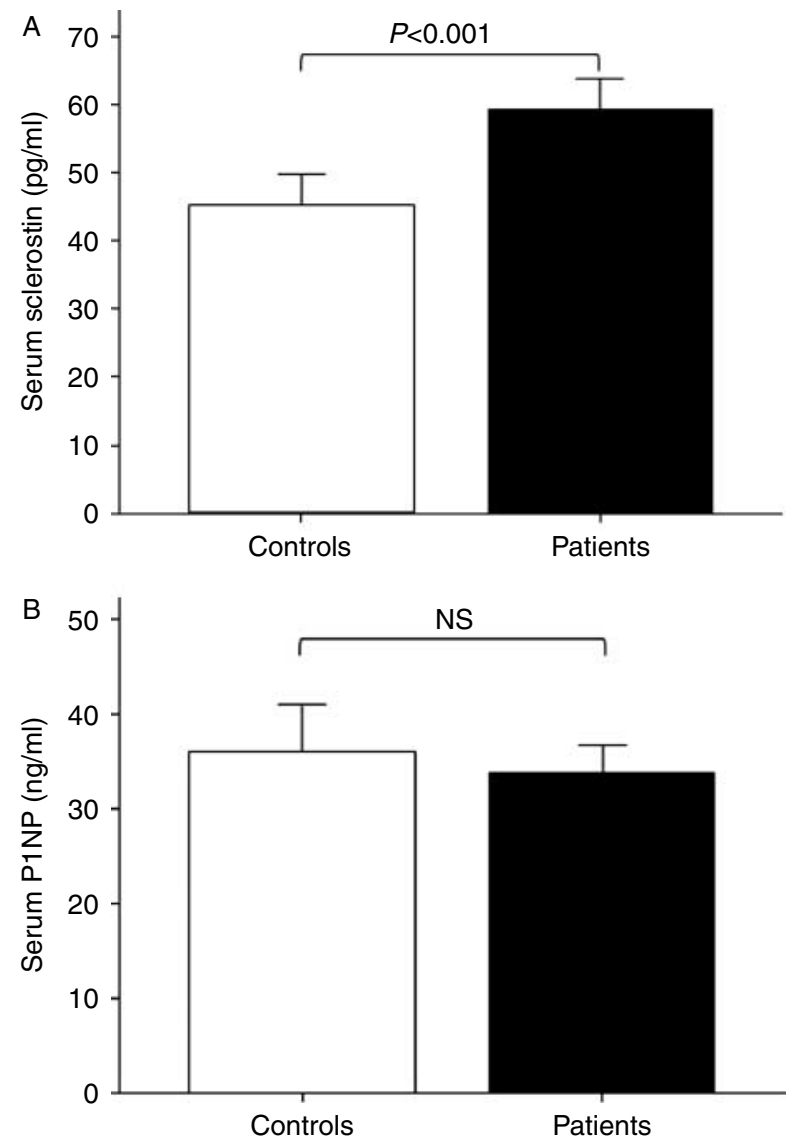

Figure 1 Serum sclerostin (A) and P1NP (B) levels in male patients with T2DM and healthy male controls. Bars represent S.E.M. $P$ values: significance of differences between groups (Student's $t$-tests). NS, nonsignificant.

significant change in these levels in patients treated with MET $(-1.8 \%$; $95 \%$ CI: -8.8 to $5.0, P=0.42)$. The difference in sclerostin response between the two treatment groups was significant $(P=0.018)$.

Serum P1NP levels increased by 3.7\% (95\% CI: -3.9 to $11.3, P=0.35)$ in the PIO group but decreased significantly by $19.1 \%$ (95\% CI: -25.5 to -12.8 , $P<0.001$ ) in the MET group (between-group difference $P<0.001)$. Serum CTX levels increased by $16.8 \%(95 \%$ CI: 4.4 to $29.1, P=0.012$ ) after treatment with PIO but decreased by $19.0 \%(95 \%$ CI: -27.1 to -10.9 , $P<0.001$ ) in the MET-treated group (between-group difference $P<0.001$ ). There was no significant change in serum calcium, phosphate, or creatinine concentrations after 24 weeks of treatment with either agent.

\section{Relationship between serum sclerostin and markers of bone turnover}

There was no significant relationship between serum sclerostin levels and either serum P1NP $(r=0.15$, $P=0.22)$ or serum CTX $(r=0.17, P=0.17)$ at baseline.
There was also no significant correlation between changes in serum sclerostin values and serum P1NP levels in all patients pooled together $(r=0.12, P=0.31)$, or in individual treatment groups (MET: $r=0.02$, $P=0.90$; PIO: $r=0.05, P=0.77$ ) (Fig. 3A). In contrast, changes in serum sclerostin levels were significantly correlated with changes in serum CTX levels in all patients pooled together $(r=0.36, P=0.002)$ and in PIO-treated patients $(r=0.39, P=0.020)$, but not in the MET-treated patients $(r=0.17, P=0.31)$ (Fig. 3B).

\section{Discussion}

We here show that circulating sclerostin levels are increased in patients with uncomplicated T2DM and respond differently to different blood glucose-lowering medications. In the presence of similar control of glycemia, MET treatment given for 24 weeks had no effect on sclerostin levels and significantly decreased levels of biochemical markers of bone turnover, whereas PIO treatment increased the serum levels of sclerostin and the bone resorption marker CTX.

The exact pathogenesis of increased bone fragility observed in patients with T2DM remains unclear. In these patients, it is well established that fractures occur at higher bone mineral density (BMD) values than in patients with osteoporosis. The increased fracture rate has also been found to be independent of the increased frequency of falls, also documented in patients with T2DM $(1,14,15)$. Changes in calcium homeostasis, increased secretion of inflammatory cytokines, and the accumulation of advanced glycation end-products have been proposed as contributory factors to the pathogenesis of increased bone fragility in T2DM $(16,17)$. The identification of osteocyte-produced sclerostin as a key regulator of bone formation by osteoblasts has initiated a number of studies on the effect of this protein on bone strength. Lack of sclerostin leads to profound increases in bone mass in humans $(13,18)$ and in animal models (19), whereas overexpression of

Table 2 Baseline anthropometric and biochemical data of male patients with T2DM treated with either metformin or pioglitazone. Values are given as mean \pm S.D.

\begin{tabular}{lccc}
\hline & $\begin{array}{c}\text { Metformin } \\
(n=37)\end{array}$ & $\begin{array}{c}\text { Pioglitazone } \\
(n=34)\end{array}$ & $\boldsymbol{P}$ value \\
\hline Age (years) & $56.5 \pm 5.4$ & $56.4 \pm 5.9$ & 0.99 \\
Weight $(\mathrm{kg})$ & $93.2 \pm 14.6$ & $91.1 \pm 12.6$ & 0.50 \\
BMl $\left(\mathrm{kg} / \mathrm{m}^{2}\right)$ & $29.3 \pm 3.8$ & $28.2 \pm 3.0$ & 0.17 \\
Time since diagnosis & $3.6 \pm 2.5$ & $4.6 \pm 2.8$ & 0.11 \\
$\quad($ years $)$ & & & \\
Sclerostin $(\mathrm{pg} / \mathrm{ml})$ & $62.4 \pm 18.9$ & $58.5 \pm 22.0$ & 0.42 \\
P1NP $(\mathrm{ng} / \mathrm{ml})$ & $35.1 \pm 11.7$ & $32.0 \pm 12.7$ & 0.28 \\
CTX $(\mathrm{pg} / \mathrm{ml})$ & $381 \pm 380$ & $294 \pm 140$ & 0.40 \\
Calcium $(\mathrm{mmol} / \mathrm{l})$ & $2.29 \pm 0.10$ & $2.28 \pm 0.11$ & 0.92 \\
Phosphate $(\mathrm{mmol} / \mathrm{l})$ & $1.00 \pm 0.16$ & $1.00 \pm 0.18$ & 0.60 \\
Creatinine $(\mu \mathrm{mol} / \mathrm{l})$ & $76.6 \pm 17.3$ & $77.3 \pm 12.7$ & 0.49 \\
\hline
\end{tabular}




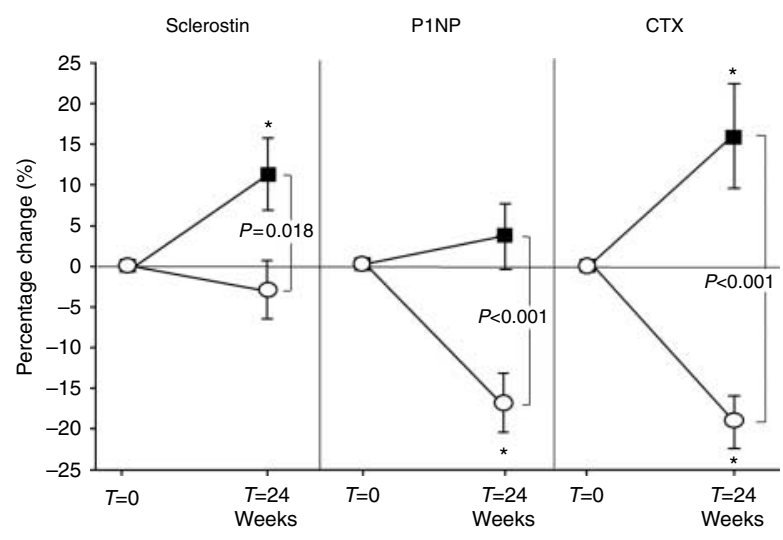

Figure 2 Mean percentage changes in serum levels of sclerostin, $\mathrm{P} 1 \mathrm{NP}$, and CTX in male patients with T2DM treated with metformin (open circles) or pioglitazone (closed squares). Bars represent the $95 \%$ confidence interval. * Significance of change from baseline within groups (one-sample $t$-test), $P<0.05$. $P$ values: significance of differences between groups (Student's $t$-tests).

sclerostin is associated with decreased mechanical strength in animal models (8). In a recent study, circulating sclerostin levels were positively associated with fracture risk in a large cohort of postmenopausal women (9). Moreover, established determinants of bone strength such as mechanical loading, parathyroid hormone, and estrogen have been shown to modulate the production and/or the secretion of sclerostin $(12,20,21)$. Our findings of increased serum sclerostin levels in patients with T2DM suggest a potential role for this protein in bone metabolism in T2DM by an as-yet unidentified mechanism. The positive correlation between serum sclerostin and insulin levels suggests a possible contribution of insulin in the production and/or secretion of sclerostin. However, in contrast to the case of osteoblasts, few or no insulin receptors could be detected in osteocytes by immunohistochemical staining (22). In our patients with T2DM, the documented increase in serum sclerostin levels was not associated with a decrease in serum levels of the bone formation marker P1NP, in agreement with a previous study (23). Another marker of bone formation, osteocalcin, particularly the undercarboxylated form, has been implicated in the regulation of insulin secretion (24). However, measurements of serum osteocalcin in patients with T2DM have provided conflicting results showing either no change or decrease $(23,25,26,27,28,29)$. We did not measure serum osteocalcin, but a significant positive relationship with serum P1NP has been previously reported in patients with T2DM $(23,28)$. Notwithstanding, our findings are in keeping with a recent study that reported higher serum sclerostin levels in patients with T2DM compared with controls but no difference in the bone formation markers serum osteocalcin and bone-specific alkaline phosphatase between T2DM patients and healthy controls (26).
In our cohort of T2DM patients, treatment with MET or PIO in combination with glimepiride improved glucose regulation to a similar degree but had different effects on serum sclerostin levels and biochemical markers of bone turnover. Treatment with MET for 24 weeks had no apparent effect on serum sclerostin levels, but significantly decreased bone turnover, as assessed by serum markers of bone formation (P1NP) and bone resorption (CTX). A decrease in bone turnover has been previously reported after MET treatment $(30,31)$, but a similar decrease in bone turnover has also been observed after improvement of glycemic control using other therapeutic regimens, such as diet or insulin administration (32). However, the different effects on bone turnover observed in our study in the PIO-treated patients despite a similar control of glucose metabolism demonstrate that the two agents have different effects on bone metabolism that are independent of their glucose-lowering action.
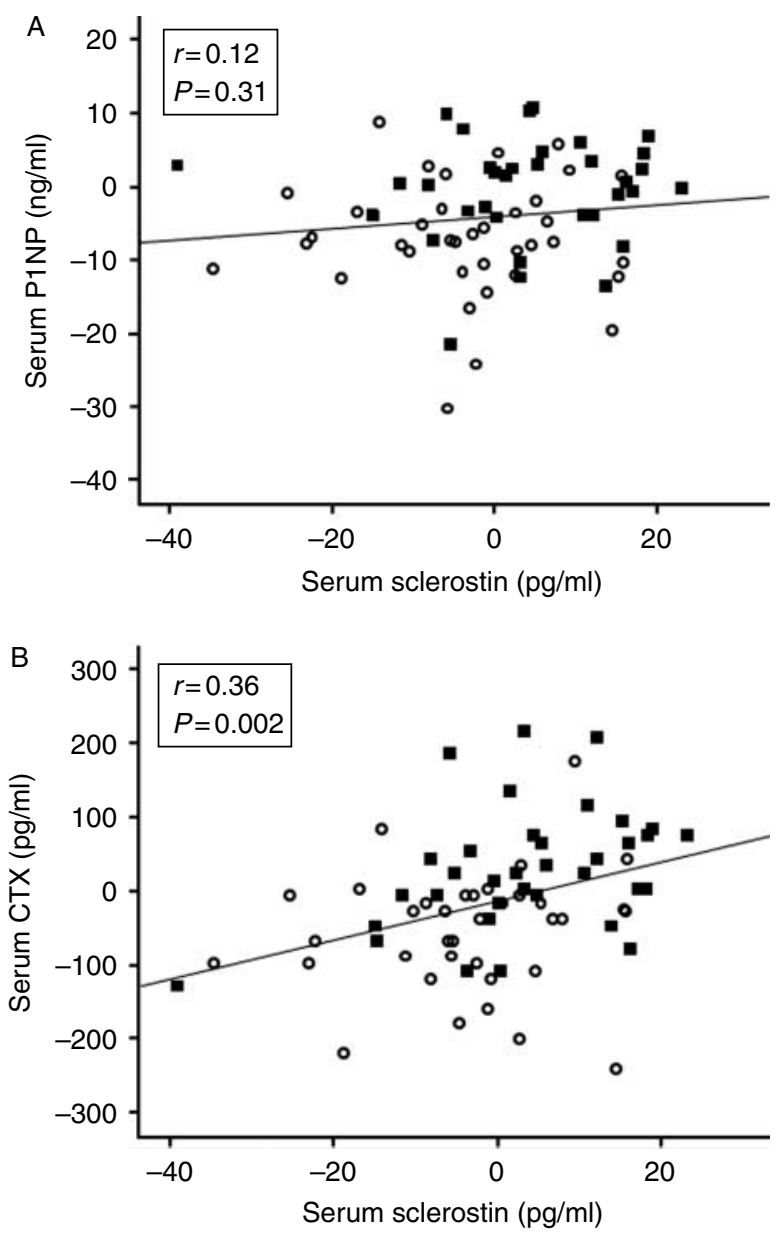

Figure 3 Relationship between changes in serum levels of sclerostin and P1NP (A) and CTX (B). Open circles represent metformin-treated patients and closed squares represent pioglitazone-treated patients. 
Our data indeed show that in contrast to MET, serum sclerostin levels increased in patients treated with PIO and that this was associated with a significant increase in serum CTX levels, despite adequate glycemic control. Over the past decade, evidence has been accumulating on the detrimental effect of TZDs on the skeleton, decreasing bone mass and increasing fracture risk in both men $(33,34,35)$ and women with diabetes mellitus $(4,33,35,36,37,38,39)$. This deleterious effect of TZDs on the skeleton is generally attributed to the activation of PPAR $\gamma$ in the bone marrow by these agents, leading to preferential stimulation of adipogenesis at the cost of osteoblastogenesis (5). Our results suggest another potential pathogenetic mechanism, namely stimulation of sclerostin production by TZDs. This finding conforms to recent in vitro data by Mabilleau et al. (6) who showed that TZDs stimulate the expression of sclerostin by osteocytes in the absence of $17 \beta$-estradiol. Although sclerostin is a well-established inhibitor of bone formation, recent evidence indicates that it can also promote osteoclastogenesis by stimulating RANKL produced by osteocytes (40). Moreover, inhibition of sclerostin in animals and humans by a specific antibody does not only lead to increased bone formation but also to decreased bone resorption $(41,42)$. Taken together, these data suggest that PIO stimulates the production of sclerostin, which would in turn increase RANKL production by osteocytes, thus resulting in a dual effect on bone metabolism, reducing bone formation and increasing bone resorption, which could explain the adverse effect of PIO on bone quality.

A limitation of our study is that it was conducted only in men with uncomplicated T2DM and our results cannot be readily extrapolated to all patients with T2DM. The study was of short duration precluding the assessment of the effect of TZDs on BMD or fracture risk.

Notwithstanding, our study shows that patients with T2DM have increased circulating sclerostin levels that might contribute to the documented increased bone fragility of these patients. Of particular clinical relevance is the finding that MET and PIO have different effects on sclerostin levels and biochemical markers of bone turnover, with MET having a clearly more favorable bone profile.

\section{Declaration of interest}

The authors declare that there is no conflict of interest that could be perceived as prejudicing the impartiality of the research reported.

\section{Funding}

This work was supported by and carried out within the FP7 programme TALOS and funded by the EC (Grant Number: TALOS:Health-F2-2008-201099). The PIRAMID study was an investigator-initiated study supported by Eli Lilly, The Netherlands, which has a partnership with Takeda, the manufacturer of pioglitazone. Metformin tablets and matching placebos were kindly provided by Merck, The Netherlands.

\section{References}

1 Vestergaard P. Discrepancies in bone mineral density and fracture risk in patients with type 1 and type 2 diabetes - a meta-analysis. Osteoporosis International $2007 \mathbf{1 8}$ 427-444. (doi:10.1007/ s00198-006-0253-4)

2 Grey A. Skeletal consequences of thiazolidinedione therapy. Osteoporosis International $2008 \quad 19$ 129-137. (doi:10.1007/ s00198-007-0477-y)

3 Betteridge DJ. Thiazolidinediones and fracture risk in patients with type 2 diabetes. Diabetic Medicine 201128 759-771. (doi:10. 1111/j.1464-5491.2010.03187.x)

4 Kahn SE, Zinman B, Lachin JM, Haffner SM, Herman WH, Holman RR, Kravitz BG, Yu D, Heise MA, Aftring RP \& Viberti G. Rosiglitazone-associated fractures in type 2 diabetes: an Analysis from A Diabetes Outcome Progression Trial (ADOPT). Diabetes Care 200831 845-851. (doi:10.2337/dc07-2270)

5 Lecka-Czernik B, Moerman EJ, Grant DF, Lehmann JM, Manolagas SC \& Jilka RL. Divergent effects of selective peroxisome proliferator-activated receptor-gamma 2 ligands on adipocyte versus osteoblast differentiation. Endocrinology $2002 \mathbf{1 4 3}$ 2376-2384. (doi:10.1210/en.143.6.2376)

6 Mabilleau G, Mieczkowska A \& Edmonds ME. Thiazolidinediones induce osteocyte apoptosis and increase sclerostin expression. Diabetic Medicine 201027 925-932. (doi:10.1111/j.1464-5491. 2010.03048.x)

7 van Bezooijen RL, Roelen BA, Visser A, van der Wee-Pals L, de Wilt E, Karperien M, Hamersma H, Papapoulos SE, ten Dijke P \& Lowik CW. Sclerostin is an osteocyte-expressed negative regulator of bone formation, but not a classical BMP antagonist. Journal of Experimental Medicine 2004199 805-814. (doi:10.1084/jem. 20031454)

8 Winkler DG, Sutherland MK, Geoghegan JC, Yu C, Hayes T, Skonier JE, Shpektor D, Jonas M, Kovacevich BR, StaehlingHampton K, Appleby M, Brunkow ME \& Latham JA. Osteocyte control of bone formation via sclerostin, a novel BMP antagonist. EMBO Journal 200322 6267-6276. (doi:10.1093/emboj/ $\operatorname{cdg} 599)$

9 Arasu A, Cawthon P, Do T, Arora P, Lui L-Y, Cauley J, Ensrud K \& Cummings S. Sclerostin and risk of hip fracture in older women. Journal of Bone and Mineral Research 201126 S143. (doi:10.1002/ jbmr.167)

10 van der Meer RW, Rijzewijk LJ, de Jong HW, Lamb HJ, Lubberink M, Romijn JA, Bax JJ, de Roos A, Kamp O, Paulus WJ, Heine RJ, Lammertsma AA, Smit JW \& Diamant M. Pioglitazone improves cardiac function and alters myocardial substrate metabolism without affecting cardiac triglyceride accumulation and highenergy phosphate metabolism in patients with well-controlled type 2 diabetes mellitus. Circulation 2009119 2069-2077. (doi:10.1161/CIRCULATIONAHA.108.803916)

11 Rijzewijk LJ, van der Meer RW, Lubberink M, Lamb HJ, Romijn JA, de Roos A, Twisk JW, Heine RJ, Lammertsma AA, Smit JW \& Diamant M. Liver fat content in type 2 diabetes: relationship with hepatic perfusion and substrate metabolism. Diabetes 201059 2747-2754. (doi:10.2337/db09-1201)

12 van Lierop AH, Witteveen JE, Hamdy NA \& Papapoulos SE. Patients with primary hyperparathyroidism have lower circulating sclerostin levels than euparathyroid controls. European Journal of Endocrinology 2010163 833-837. (doi:10.1530/EJE10-0699)

13 van Lierop AH, Hamdy NA, Hamersma H, van Bezooijen RL, Power J, Loveridge N \& Papapoulos SE. Patients with sclerosteosis and disease carriers: human models of the effect of sclerostin on bone turnover. Journal of Bone and Mineral Research 201126 2804-2811. (doi:10.1002/jbmr.474)

14 Vestergaard P, Rejnmark L \& Mosekilde L. Diabetes and its complications and their relationship with risk of fractures in type 1 and 2 diabetes. Calcified Tissue International 200984 45-55. (doi:10.1007/s00223-008-9195-5) 
15 Yamamoto M, Yamaguchi T, Yamauchi M, Kaji H \& Sugimoto T. Diabetic patients have an increased risk of vertebral fractures independent of BMD or diabetic complications. Journal of Bone and Mineral Research 200924 702-709. (doi:10.1359/jbmr.081207)

16 de Paula FJ, Horowitz MC \& Rosen CJ. Novel insights into the relationship between diabetes and osteoporosis. Diabetes/Metabolism Research and Reviews 201026 622-630. (doi:10.1002/dmrr. 1135)

17 Merlotti D, Gennari L, Dotta F, Lauro D \& Nuti R. Mechanisms of impaired bone strength in type 1 and 2 diabetes. Nutrition, Metabolism \& Cardiovascular Diseases 201020 683-690. (doi:10. 1016/j.numecd.2010.07.008)

18 Gardner JC, van Bezooijen RL, Mervis B, Hamdy NA, Lowik CW, Hamersma H, Beighton P \& Papapoulos SE. Bone mineral density in sclerosteosis; affected individuals and gene carriers. Journal of Clinical Endocrinology and Metabolism $2005 \quad 906392-6395$. (doi:10.1210/jc.2005-1235)

19 Li X, Ominsky MS, Niu QT, Sun N, Daugherty B, D’Agostin D, Kurahara C, Gao Y, Cao J, Gong J, Asuncion F, Barrero M, Warmington K, Dwyer D, Stolina M, Morony S, Sarosi I, Kostenuik PJ, Lacey DL, Simonet WS, Ke HZ \& Paszty C. Targeted deletion of the sclerostin gene in mice results in increased bone formation and bone strength. Journal of Bone and Mineral Research 200823 860-869. (doi:10.1359/jbmr.080216)

20 Gaudio A, Pennisi P, Bratengeier C, Torrisi V, Lindner B, Mangiafico RA, Pulvirenti I, Hawa G, Tringali G \& Fiore CE. Increased sclerostin serum levels associated with bone formation and resorption markers in patients with immobilization-induced bone loss. Journal of Clinical Endocrinology and Metabolism 201095 2248-2253. (doi:10.1210/jc.2010-0067)

21 Modder UI, Clowes JA, Hoey K, Peterson JM, McCready L, Oursler MJ, Riggs BL \& Khosla S. Regulation of circulating sclerostin levels by sex steroids in women and in men. Journal of Bone and Mineral Research 201126 27-34. (doi:10.1002/jbmr. 128)

22 Thomas DM, Hards DK, Rogers SD, Ng KW \& Best JD. Insulin receptor expression in bone. Journal of Bone and Mineral Research 199611 1312-1320. (doi:10.1002/jbmr.5650110916)

23 Iglesias P, Arrieta F, Pinera M, Botella-Carretero JI, Balsa JA, Zamarron I, Menacho M, Diez JJ, Munoz T \& Vazquez C. Serum concentrations of osteocalcin, procollagen type $1 \mathrm{~N}$-terminal propeptide and beta-CrossLaps in obese subjects with varying degrees of glucose tolerance. Clinical Endocrinology 201175184 188. (doi:10.1111/j.1365-2265.2011.04035.x)

24 Ferron M, Hinoi E, Karsenty G \& Ducy P. Osteocalcin differentially regulates beta cell and adipocyte gene expression and affects the development of metabolic diseases in wild-type mice. PNAS 2008 105 5266-5270. (doi:10.1073/pnas.0711119105)

25 Achemlal L, Tellal S, Rkiouak F, Nouijai A, Bezza A, Derouiche el M, Ghafir D \& El Maghraoui A. Bone metabolism in male patients with type 2 diabetes. Clinical Rheumatology 200524 493-496. (doi:10.1007/s10067-004-1070-9)

26 Garcia-Martin A, Rozas-Moreno P, Reyes-Garcia R, MoralesSantana S, Garcia-Fontana B, Garcia-Salcedo JA \& MunozTorres M. Circulating levels of sclerostin are increased in patients with type 2 diabetes mellitus. Journal of Clinical Endocrinology and Metabolism 201197 234-241. (doi:10.1210/jc.2011-2186)

27 Isaia GC, Ardissone P, Di SM, Ferrari D, Martina V, Porta M, Tagliabue M \& Molinatti GM. Bone metabolism in type 2 diabetes mellitus. Acta Diabetologica 199936 35-38. (doi:10.1007/ s005920050142)

28 Kindblom JM, Ohlsson C, Ljunggren O, Karlsson MK, Tivesten A, Smith U \& Mellstrom D. Plasma osteocalcin is inversely related to fat mass and plasma glucose in elderly Swedish men. Journal of Bone and Mineral Research 200924 785-791. (doi:10.1359/jbmr. 081234)
29 Rosato MT, Schneider SH \& Shapses SA. Bone turnover and insulin-like growth factor I levels increase after improved glycemic control in noninsulin-dependent diabetes mellitus. Calcified Tissue International 199863 107-111. (doi:10.1007/s002239900498)

30 Zinman B, Haffner SM, Herman WH, Holman RR, Lachin JM, Kravitz BG, Paul G, Jones NP, Aftring RP, Viberti G \& Kahn SE. Effect of rosiglitazone, metformin, and glyburide on bone biomarkers in patients with type 2 diabetes. Journal of Clinical Endocrinology and Metabolism 201095 134-142. (doi:10.1210/ jc.2009-0572)

31 Capoglu I, Ozkan A, Ozkan B \& Umudum Z. Bone turnover markers in patients with type 2 diabetes and their correlation with glycosylated haemoglobin levels. Journal of International Medical Research 200836 1392-1398.

32 Okazaki R, Totsuka Y, Hamano K, Ajima M, Miura M, Hirota Y, Hata K, Fukumoto S \& Matsumoto T. Metabolic improvement of poorly controlled noninsulin-dependent diabetes mellitus decreases bone turnover. Journal of Clinical Endocrinology and Metabolism 199782 2915-2920. (doi:10.1210/jc.82.9.2915)

33 Dormuth CR, Carney G, Carleton B, Bassett K \& Wright JM. Thiazolidinediones and fractures in men and women. Archives of Internal Medicine 2009169 1395-1402. (doi:10.1001/archinternmed.2009.214)

34 Douglas IJ, Evans SJ, Pocock S \& Smeeth L. The risk of fractures associated with thiazolidinediones: a self-controlled case-series study. PLoS Medicine 20096 e1000154. (doi:10.1371/journal. pmed.1000154)

35 Meier C, Kraenzlin ME, Bodmer M, Jick SS, Jick H \& Meier CR. Use of thiazolidinediones and fracture risk. Archives of Internal Medicine 2008168 820-825. (doi:10.1001/archinte.168.8.820)

36 Bilik D, McEwen LN, Brown MB, Pomeroy NE, Kim C, Asao K, Crosson JC, Duru OK, Ferrara A, Hsiao VC, Karter AJ, Lee PG, Marrero DG, Selby JV, Subramanian U \& Herman WH. Thiazolidinediones and fractures: evidence from translating research into action for diabetes. Journal of Clinical Endocrinology and Metabolism 201095 4560-4565. (doi:10.1210/jc.2009-2638)

37 Habib ZA, Havstad SL, Wells K, Divine G, Pladevall M \& Williams LK. Thiazolidinedione use and the longitudinal risk of fractures in patients with type 2 diabetes mellitus. Journal of Clinical Endocrinology and Metabolism 2010 95 592-600. (doi:10. 1210/jc.2009-1385)

38 Jones SG, Momin SR, Good MW, Shea TK \& Patric K. Distal upper and lower limb fractures associated with thiazolidinedione use. American Journal of Managed Care 200915 491-496.

39 Solomon DH, Cadarette SM, Choudhry NK, Canning C, Levin R \& Sturmer T. A cohort study of thiazolidinediones and fractures in older adults with diabetes. Journal of Clinical Endocrinology and Metabolism 200994 2792-2798. (doi:10.1210/jc.2008-2157)

40 Wijenayaka AR, Kogawa M, Lim HP, Bonewald LF, Findlay DM \& Atkins GJ. Sclerostin stimulates osteocyte support of osteoclast activity by a RANKL-dependent pathway. PLOS ONE 20116 e25900. (doi:10.1371/journal.pone.0025900)

41 Marenzana M, Greenslade K, Eddleston A, Okoye R, Marshall D, Moore A \& Robinson MK. Sclerostin antibody treatment enhances bone strength but does not prevent growth retardation in young mice treated with dexamethasone. Arthritis \& Rheumatology 2011 63 2385-2395. (doi:10.1002/art.30385)

42 Padhi D, Jang G, Stouch B, Fang L \& Posvar E. Single-dose, placebo-controlled, randomized study of AMG 785, a sclerostin monoclonal antibody. Journal of Bone and Mineral Research 2011 26 19-26. (doi:10.1002/jbmr.173)

Received 9 December 2011

Revised version received 10 January 2012

Accepted 20 January 2012 